ROCZNIK PRZEMYSKI t. 57

LITERATURA I JEZYK z. 2 (25) 2021

\author{
DAWID KOPA (Kraków) \\ ORCID: 0000-0003-4741-2048
}

\title{
„PIEŚŃ O CNYCH LISOWSKICH KOZAKACH”
}

\begin{abstract}

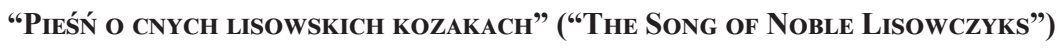

The paper remembers the song "Pieśn o cnych lisowskich kozakach", whose authorship is disputable. The song was written as part of propaganda directed at the nobility opinion opposed to the actions of the Lisowczyks. Compared with previously published editions, the present one brings out a full message of the song, collects information on the fates of the copies of the first edition and explains misunderstandings resulting from the academic debate going on since the $19^{\text {th }} \mathrm{c}$.

Keywords: "Pieśń o cnych lisowskich kozakach" ("The Song of Noble Lisowczyks"), the Lisowczyks, critical edition, song, Old Polish literature

Słowa kluczowe: Pieśń o cnych lisowskich kozakach, lisowczycy, edycja krytyczna, pieśń, literatura staropolska

Wśród utworów o lisowczykach, napisanych prawdopodobnie przez Wojciecha Dembołęckiego, znajduje się Pieśń o cnych lisowskich kozakach ${ }^{1}$. Budząca wątpliwości kwestia atrybucji tego utworu posiada już swoją literaturę i nie jest w tym miejscu przedmiotem mojego zainteresowania ${ }^{2}$. Wydany po raz pierwszy po

\footnotetext{
${ }^{1}$ Wbrew pierwodrukowi w literaturze przyjął się tytuł Pieśń o cnych kozakach lisowskich.

${ }^{2}$ J.B. Zimorowic, Żywot kozaków lisowskich, ocenił i wyd. K.J. Heck, Lwów 1886, s. 38, 43-45, 49; Z. Mocarski, [rec.] Dr. K. Badecki: ,Literatura mieszczańska w Polsce XVII wieku. Monografija bibliograficzna", Lwów 1925, str. 543. Tenże: Nieodszukane pierwodruki literatury mieszczańskiej w Polsce XVII w.” Lwów (osobne odbicie z „Pamiętnika Literackiego” $r$. XXII i XXIII wytloczone na Międzynarodowy Kongres bibliotekarzy i przyjaciót ksiązki w Pradze) 1926, str. 43, „Zapiski Towarzystwa Naukowego w Toruniu" 1926, t. 7, nr 4, s. 124-125; M. Kochańska, Ksiadz Wojciech Dembołęcki z Konojad, „Zeszyty Naukowe Uniwersytetu Wrocławskiego”, seria A: Prace Literackie, nr 1, Wrocław 1956, s. 111. Nie do końca jasna jest opinia J. Nowaka-Dłużewskiego, który w tekście głównym uznaje Wojciecha Dembołęckiego za możliwego autora, natomiast w przypisie taką możliwość wyklucza (Okolicznościowa poezja polityczna w Polsce: Zygmunt III, Warszawa 1971, s. 273, 409-410, przyp. 51); R. Sztyber, Wstęp, [w:] Wojciech Dembołęcki o lisowczykach wierszem i proza (1620-1621), wyd. R. Sztyber, Warszawa 2011, s. 125-128.
} 
1619 r. $^{3}$ druk, w którym pomieszczono wymieniony wyżej utwór, nosi tytuł: Pieśni o cnych lisowskich kozakach abo pogrom Czechów i kalwinistów przez lisowczyki ${ }^{4}$. Drugie wydanie jest zatytułowane: Pogrom abo porażka Czechów i kalwinistów przez lisowczyki roku Pańskiego 1620, różnemi czasy raz po raz ośm $r a z y^{5}$. Na drugiej stronie drugiego wydania umieszczono tytuł: Pierwsza porażka Czechów przez lisowczyki ${ }^{6}$. Każde z tych wydań zawiera Pieśń o cnych lisowskich kozakach, której ostatnim wydawcą jest Radosław Sztyber. Zielonogórski badacz uczynił podstawą swojej edycji tekst zamieszczony przez Kazimierza Władysława Wójcickiego w Obrazach starodawnych z 1843 r. ${ }^{7}$ Wcześniej, także za Wójcickim przedrukował go w roku 1844, w niezmienionej formie, Wojciech Dzieduszycki ${ }^{8}$. Z kolei Juliusz Nowak-Dłużewski, omawiając ten utwór, przywołał fragmenty, które nie znalazły się w wydaniu Sztybera, na przykład:

Tu szesnaście tysięcy Czechów legło krwawie,

Tędy męstwo lisowskich zakwitnęło w sławie,

Stąd wziąwszy dzielność śmiałą, męstwem słyną wszędzie,

Dobry znak, pan Bóg z nami, któż przeciw nam będzie?

Ten epigramat umieszczono pod ryciną zdobiącą kartę tytułową. Nowak-Dłużewski odwołał się jeszcze do dwóch innych fragmentów, których nie znajdziemy w wydaniu Sztybera. W przypisie stwierdził natomiast odnośnie do wydań, że istnieją „Dwa wydania anonimowe współczesne; drugie wydanie pod zmienionym tytułem Pogrom abo porażka Czechów i kalwinistów przez lisowczyków roku 1620 rożnymi czasy raz po raz ośm razy" ${ }^{10}$. Jak widać w zacytowanym przypisie Nowaka-Dłużewskiego, nie ma żadnych danych, na podstawie których można by stwierdzić, czy opierał się na druku dziewiętnastowiecznym, czy też na starodruku. Data, która

${ }^{3}$ A. Kotarska przyjmuje, że najpewniejsza możliwa data wydania to 1623 r., natomiast M. Kochańska skłania się ku dacie 1621, zob. A. Kotarska, Pieśni o Lisowczykach, „Pamiętnik Literacki” 1952, nr 40, s. 1039; M. Kochańska, Ksiądz..., s. 110.

${ }^{4}$ Biblioteka Jagiellońska, sygn. 1461 I, W. Dembołęcki, Pieśni o cnych lisowskich kozakach abo pogrom Czechów i kalwinistów przez lisowczyki roku Pańskiego 1620, różnemi czasy raz po raz ośm razy; Biblioteka Gdańska PAN, sygn. NI 848 adl. 9, W. Dembołęcki, Pieśni o cnych lisowskich kozakach abo pogrom Czechów i kalwinistów przez lisowczyki roku Pańskiego 1620, różnemi czasy raz po raz ośm razy; Biblioteka Kórnicka PAN, sygn. 12850, W. Dembołęcki, Pieśni o cnych lisowskich kozakach abo pogrom Czechów i kalwinistów przez lisowczyki roku Pańskiego 1620, różnemi czasy raz po raz ośm razy. Egzemplarz drugiego wydania przechowywany w Bibliotece PAU w Krakowie pod sygn. 6256 - znany jeszcze w $1952 \mathrm{r}$. A. Kotarskiej (Pieśni ..., s. 1037) nie został odnaleziony i prawdopodobnie zaginął. Obecnie pod tą sygnaturą w Bibliotece PAU znajduje się inne dzieło. Znany mi egzemplarz drugiego wydania, także zawierający w tytule datę 1620 r., znajduje się w Bibliotece Gdańskiej PAN, oznaczony sygnaturą NI 788 adl. 24.

${ }^{5}$ Biblioteka Gdańska PAN, sygn. NI 788 adl. 24, Pogrom abo porażka Czechów i kalwinistów przez lisowczyki roku Pańskiego 1620, różnemi czasy raz po raz ośm razy, s. 1.

${ }^{6}$ Ibidem, s. 2.

${ }^{7}$ R. Sztyber, Wstęp, op. cit., s. 198; K.W. Wójcicki, Obrazy starodawne, t. 1, Warszawa 1843 , s. 74-76.

${ }^{8}$ W. Dzieduszycki, Krótki rys dziejów i spraw lisowczyków, t. 2, Lwów 1844, s. 369-370.

${ }^{9}$ J. Nowak-Dłużewski, op. cit., s. 271.

${ }^{10}$ Ibidem, s. 409. 
stanowi część tytułu, nie może być tego świadectwem. Dalsze dwa niegraniczące ze sobą fragmenty utworu przytoczone przez Nowaka-Dłużewskiego to:

\footnotetext{
Tamże też Bukowy waleczny przybywszy, Nad Dunajem się z Tampirem złączywszy, Ujźreli Czechów wielkość nie zliczoną, Kędy lisowscy do nich idą stroną, Przez Dunaj prosto z Morawy przybywszy ${ }^{11}$, Męstwa dostali, Czechy rozgromiwszy ${ }^{12}$
}

oraz:

W małym swym poczcie wiele dokazali I tak swym szczęściem to rycerskie plemię Zewsząd plundruje możną czeską ziemię Sława ich kwitnie, męstwa dokazują, A niepodobnie w siłach swych przodują ${ }^{13}$.

W trakcie przeglądania przechowywanej w Bibliotece Jagiellońskiej w Krakowie spuścizny po Karolu Badeckim odnalazłem maszynopis zawierający utwory przygotowywane przez niego do edycji, w ramach współpracy z Instytutem Badań Literackich PAN w Warszawie ${ }^{14}$. Miały one być wydane w zbiorze Świecka pieśń ludowa polskiego baroku ${ }^{15}$. Nigdy się jednak nie ukazały. Wśród pieśni, które były przygotowywane do wydania, znajdowała się także Pieśń o cnych kozakach lisowskich ${ }^{16}$. Na przeszkodzie stanęła śmierć Badeckiego w roku 1953. Rodzina badacza w tym samym roku przekazała materiały do Biblioteki Jagiellońskiej ${ }^{17}$. Przekaz utworu przechowywany w spuściźnie po bibliotekarzu i archiwiście liczy sześćdziesiąt cztery wersy, a zatem o dwadzieścia osiem więcej niż ten w wydaniu Sztybera ${ }^{18}$. Zasadniczym celem niniejszej edycji jest dostarczenie czytelnikowi pełnego tekstu utworu opartego na pierwodruku, dotychczasowi edytorzy nie zdołali tego dokonać. Poznanie przekazu tekstu autentycznego pieśni będzie stanowić podbudowę do dalszych badań nad jej atrybucją.

Podstawą niniejszej edycji jest egzemplarz pierwszego wydania przechowywany w Bibliotece Gdańskiej PAN ${ }^{19}$. Będzie on dalej określany jako D1. Jest identyczny

${ }^{11}$ J.K. Heck, Żywot..., s. 43. Od słów: „Przez Dunaj” aż do „wiele dokazali” cytuje ten fragment z dodatkowym wersem: „Raz po raz z lutry ośm bitew wygrali”.

${ }^{12}$ J. Nowak-Dłużewski, op. cit., s. 273.

${ }^{13}$ Ibidem.

${ }^{14} \mathrm{~W}$ obszernej korespondencji w sprawie wydania utworów IBL PAN w Warszawie reprezentowała Maria Renata Mayenowa.

${ }^{15}$ A. Knot, Karol Badecki - archiwista i bibliotekarz, „Pamiętnik Literacki” 1953, z. 3-4, s. 401.

${ }^{16}$ Biblioteka Jagiellońska, Spuścizna Karola Badeckiego, nr 7779 III, s. 88-91; nr 7780, t. 1, s. $162-164$.

${ }^{17}$ Inwentarz rękopisów Biblioteki Jagiellońskiej, cz. 1 [4], nr 7001-8000, Kraków 1966, s. 220.

${ }^{18}$ Pieśni o cnych kozakach lisowskich, [w:] Wojciech Dembołęcki o lisowczykach wierszem i prozq (1620-1621), op. cit., s. 252-255, w. 1-36.

${ }^{19}$ Biblioteka Gdańska PAN, sygn. NI 848 adl. 9. 
z egzemplarzami przechowywanymi w Bibliotece Jagiellońskiej w Krakowie pod sygnaturą 1461 I oraz w Bibliotece Kórnickiej PAN pod sygnaturą 12850. Wydanie drugie będzie dalej określane jako D2 ${ }^{20}$. Niniejsza edycja kieruje się regułami obowiązującymi w edytorstwie nowożytnych zabytków dawnego piśmiennictwa (typ B). Zostały one wyłożone w Zasadach wydawania tekstów staropolskich ${ }^{21}$.

$*$

Pieśni o cnych lisowskich kozakach abo pogrom Czechów i kalwinistów przez lisowczyki roku Pańskiego 1620, różnemi czasy raz po raz ośm razy. Pierwsza porażka Czechów przez lisowczyki to tytuł druku ulotnego, którego pierwsze wydanie zawierające dwie pieśni - miało miejsce w 1620 r. Pierwsza z nich to Pogrom Czechów i kalwinistów przez lisowczyki roku Pańskiego 1620 pierwsza porażka Czechów przez lisowczyki. Druga, której dotychczasowe wydania trzeba uznać za wystarczające i kompletne, to: Na pamiątkę nieśmiertelna pułkownika KIM niezwyciężonego Józefa Aleksandra Lisowskiego 22. W tytule: Pieśni o cnych lisowskich kozakach abo pogrom Czechów i kalwinistów przez lisowczyki roku Pańskiego 1620, różnemi czasy raz po raz ośm razy. Pierwsza porażka Czechów przez lisowczyki, po „ośm razy” następuje przerwa na zapis nutowy zaopatrzony w następujący podpis: „dla muzyków te nuty, bo ci przecie znają co ut remifasola, często z nich śpiewają".

W D2 zamiast wersu: „Wieczna sromota i nienagrodzona” jest nagłówek: „Pogrom”. „Wieczna sromota i nienagrodzona” to pierwszy wers Pieśni V z Ksiag wtórych Jana Kochanowskiego ${ }^{23}$.

\section{Pieśni}

o cnych lisowskich kozakach abo pogrom Czechów i kalwinistów przez lisowczyki roku Pańskiego 1620, różnemi czasy raz po raz ośm razy ${ }^{24}$

Dla muzyków te nuty, bo ci przecie znają co ut remifasola, często z nich śpiewają

\section{Pierwsza porażka Czechów przez lisowczyki}

Tu szesnaście tysięcy Czechów legło krwawie, Kędy męstwo Lisowskich zakwitnęło w sławie, Stąd wziąwszy dzielność śmiałą, męstwem słyną wszędzie, Dobry znak, Pan Bóg z nami! któż przeciw nam będzie?

\footnotetext{
${ }^{20}$ Biblioteka Gdańska PAN, sygn. NI 788 adl. 24.

${ }^{21}$ Zasady wydawania tekstów staropolskich. Projekt, przykłady, oprac. J. Woronczak, Wrocław 1955, s. 93-100; por. też K. Górski, Tekstologia i edytorstwo dziet literackich, Warszawa 1978, s. $254-258$.

${ }^{22}$ Wojciech Dembotęcki o lisowczykach wierszem i proza (1620-1621), op. cit., s. 256.

${ }^{23}$ J. Kochanowski, Dzieła polskie, t. 1, oprac. J. Krzyżanowski, Warszawa 1967, s. 280.

${ }^{24}$ Słowa „różnemi czasy raz po raz ośm razy” odnoszą się do licznych zwycięstw lisowczyków. Jest to widoczne w dalszej części utworu.
} 
Nota jako „Wieczna sromota i nienagrodzona...”25.

$5 \quad$ Wieszczy Apollo, weźmi harfę złotą, A sam przy harfie zaśpiewaj z ochotą O cnym rycerstwie, walecznych kozakach, Wszędzie szczęśliwych lisowskich junakach,

Którzy wszerz i wdłuż Moskwę przebieżawszy

10 I bisurmańcom ${ }^{26} \mathrm{w}$ garle się oparłszy, Bez żadnej szkody swej to bystre plemię Przeszło wołoską i węgierską ziemię.

Pod Humanajcem ${ }^{27}$ męstwa dokazali I pod Patakiem ${ }^{28}$ lutrom się znać dali.

15 Nawet o Czechy mężnie się oparłszy, W sławie swej kwitną, siłę im wydarłszy.

Cesarz Ferdynand ${ }^{29} \mathrm{w}$ Wiedniu sam był głową, Czechowie z Węgry, przypadłszy namową ${ }^{30}$, Chcieli ubieżeć Wiedeń zdradą wielką

20 I na to słali armaturę wszelką.

Ale zabieżał temu Tampir ${ }^{31}$ mężny, Jak drugi Kokles ${ }^{32}$ rzymski, mąż potężny

\footnotetext{
${ }^{25}$ Nota miała przybliżyć czytelnikowi znaną ówcześnie melodię, na jaką należało śpiewać Pieśn Wojciecha Dembołęckiego.

${ }^{26}$ Bisurmanin to staropolska nazwa muzułmanina.

${ }^{27}$ Miasto Humienne w Królestwie Węgierskim, gdzie 23 XI 1619 r. odbyła się bitwa. W wyniku zwycięstwa lisowczyków nad oddziałami Jerzego Rakoczego powstańcy czescy i wojska księcia siedmiogrodzkiego Gábora Bethlena musieli odstąpić od oblężenia Wiednia, co uratowało miasto od zdobycia przez oblegających.

${ }^{28}$ Miejscowość Sárospatak położona w dzisiejszych północno-wschodnich Węgrzech była na drodze lisowczyków punktem, z którego zawrócili w kierunku Koszyc i granic Rzeczpospolitej.

${ }^{29}$ Ferdynand II Habsburg 28 VIII 1619 r. we Frankfurcie nad Menem został wybrany przez zgromadzenie wyborcze elektorów na cesarza rzymskiego narodu niemieckiego.

${ }^{30} \mathrm{~W}$ zmowie.

${ }^{31}$ Henri Dampierre żył w latach 1580-1620, był jednym z dowódców wojsk cesarskich. Pochodził z Alzacji. Wkraczając do Czech, uniemożliwił przybycie pod Wiedeń dowódcy wojsk protestanckich, hrabiemu Thurnowi, wraz z jego armią.

${ }^{32}$ Horatius Cocles, bohater rzymski, który w czasie mającego miejsce w VI w. p.n.e. najazdu Etrusków na Rzym swoim podtrzymywaniem obrony uniemożliwił zniszczenie mostu na Tybrze, po czym w pełnej zbroi przepłynął tę rzekę.
} 
Zdradę ujrzawszy, zrzucił most szeroki, Na rzece Donie ${ }^{33}$ pod miastem wysoki.

25 A potym swój czas tamże upatrzywszy, A z Francuzami wespół się złączywszy, Bił Czechy mężnie, niedowiarki gromił, Niejeden kalwin tam pióro uronit ${ }^{34}$.

Tamże też Bukwoj ${ }^{35}$ waleczny przybywszy,

30 Nad Dunajcem się z Tampirem ${ }^{36}$ złączywszy, Ujrzeli Czechów wielkośćc ${ }^{37}$ niezliczoną, Kędy lisowscy do nich iną stroną

Przez Dunaj prosto z Morawy przybywszy, Męstwa dostali, Czechy rozgromiwszy,

35 Raz po raz z lutry ośm bitew wygrali,

$\mathrm{W}$ małym swym poczcie ${ }^{38}$ wiele dokazali.

I tak swym szczęściem to rycerskie plemię Zewsząd plundruje $\mathrm{e}^{39}$ możną czeską ziemię. Sława ich kwitnie, męstwa dokazują,

40 A niepodobnie w siłach swych przodkują ${ }^{40}$.

Jeden lisowczyk, Birula nazwany, Był samodziesiąt ${ }^{41}$ na czatę wysłany. Ujźrał chorągiew czeską we stu koni, Uderzył na nię nagle, że do broni

45 Nie mogli prędko przypaść niebożęta, Tak je wysiekli oni kozaczęta. Jednych pobieli, drugich rozgromili, A siedmi ${ }^{42}$ żywo Czechów ułapili.

${ }^{33}$ Dunaj płynący przez Wiedeń.

${ }^{34}$ Kalwini są tu przyrównani do drobiu skubanego z piór.

${ }^{35}$ Charles Bucquoi (1571-1621) należał do dowódców katolickich wojsk cesarskich. Dowodzenie objął w $1618 \mathrm{r}$.

${ }^{36}$ Por. przyp. 31.

${ }^{37}$ Wielka ilość.

${ }^{38}$ Oddział żołnierzy.

${ }^{39}$ Plądruje.

${ }^{40}$ Nabierają sił.

${ }^{41} \mathrm{Z}$ dziewięcioma osobami towarzyszącymi.

${ }^{42}$ Siedmiu. 
$\mathrm{Z}$ wielką zdobyczą nazad się wracając,

$50 \quad$ „Tu sem, bratryki!” - śmiele wykrzykając,

Przywiedli więźniów do obozu swego

I tak Bóg wspomógł kozaka chudego.

Wszechmocny królu nieba wysokiego,

Tobie bądź wieczna chwała ze wszytkiego,

55 Racz błogosławić i do końca temu

Mężnych lisowskich rycerstwu zacnemu,

Aby swą siłą, nadstawiając czoła,

Oparli się aż u Adrianopola,

Gdzie miał stolicę swą przedtym poganin,

60 Bezecny Turczyn, sprośny bisurmanin ${ }^{43}$.

Niech już Ismael ${ }^{44}$ precz nam z oczu zniknie,

Niech chrześcijaństwo po wszem świecie kwitnie,

Niech z twej owczarnie pasterz światem rządzi,

Tak twa owieczka żadna nie zabłądzi.

\section{Zasady transkrypcji}

W edycji uwspółcześniono pisownię wielkich i małych liter. Modernizacji poddano także pisownię łączną i rozdzielną. Jednakże w niektórych wypadkach zachowano dawną pisownię i interpunkcję, kierując się zamiarem niezaburzania układu rymów, rytmu, podziału intonacyjno-składniowego.

Zachowano dawną fleksję. Pozostawiono łączną pisownię form potym, przedtym. W wyrazach obcego pochodzenia zawierających dyftongi zastosowano pisownię polską. Nie oznaczano kreskowania tzw. a jasnego (á). Zastosowano dzisiejszą pisownię liter $i, j y$, na przykład: Dunaycem $\rightarrow$ Dunajcem. Samogłoski nosowe oddano według współczesnych oznaczeń. Pisownia spółgłosek dźwięcznych i bezdźwięcznych została poddana regułom dzisiejszej ortografii. Zachowano imiona i nazwy miejscowe obcego pochodzenia, przy czym transkrybowano je, likwidując wzdłużenie w grupach samogłoskowych. Pozostawiono formy oboczne, na przykład: wszystkiego/wszytkiego. Nie zachowano archaicznych grup spółgłoskowych, na przykład: ujrzawszy/ujśrawszy.

\footnotetext{
${ }^{43}$ Zob. przyp. 26.

${ }^{44}$ Imię stanowiące ogólne określenie wyznawców islamu, wywodzące się od syna biblijnego Abrahama i niewolnicy Hagar.
} 


\section{Bibliografia}

\section{Źródla}

Biblioteka Gdańska PAN, sygn. NI 788 adl. 24, W. Dembołęcki, Pogrom abo porażka Czechów i kalwinistów przez lisowczyki roku Pańskiego 1620, różnemi czasy raz po raz ośm razy.

Biblioteka Gdańska PAN, sygn. NI 848 adl. 9, W. Dembołęcki, Pieśni o cnych lisowskich kozakach abo pogrom Czechów i kalwinistów przez lisowczyki roku Pańskiego 1620, różnemi czasy raz po raz ośm razy.

Biblioteka Jagiellońska, Spuścizna Karola Badeckiego, nr 7779 III, s. 88-91; nr 7780, t. 1, s. 162-164. Biblioteka Jagiellońska, sygn. 1461 I, W. Dembołęcki, Pieśni o cnych lisowskich kozakach abo pogrom Czechów i kalwinistów przez lisowczyki roku Pańskiego 1620, różnemi czasy raz po raz ośm razy.

Biblioteka Kórnicka PAN, sygn. 12850, W. Dembołęcki, Pieśni o cnych lisowskich kozakach abo pogrom Czechów i kalwinistów przez lisowczyki roku Pańskiego 1620, różnemi czasy raz po raz ośm razy.

W. Dembołęcki, Przewagi elearów polskich co ich niegdy lisowczykami zwano, oprac. R. Sztyber, Toruń 2005.

J. Kochanowski, Dzieła polskie, t. 1, oprac. J. Krzyżanowski, Warszawa 1967.

J. Nowak-Dłużewski, Okolicznościowa poezja polityczna w Polsce: Zygmunt III, Warszawa 1971. Pieśni o cnych kozakach lisowskich, [w:] Wojciech Dembotęcki o lisowczykach wierszem i proza (1620-1621), wyd. R. Sztyber, Warszawa 2011, s. 252-255, w. 1-36.

\section{Opracowania}

W. Dzieduszycki, Krótki rys dziejów i spraw Lisowczyków, t. 2, Lwów 1844.

K. Górski, Tekstologia i edytorstwo dziet literackich, Warszawa 1978.

Inwentarz rękopisów Biblioteki Jagiellońskiej, cz. 1 [4], nr 7001-8000, Kraków 1966.

A. Knot, Karol Badecki - archiwista i bibliotekarz, „Pamiętnik Literacki” 1953, z. 3-4, s. 392-404.

M. Kochańska, Ksiądz Wojciech Dembołęcki z Konojad, „Zeszyty Naukowe Uniwersytetu Wrocławskiego", seria A: Prace Literackie, nr 1, Wrocław 1956, s. 101-143.

A. Kotarska, Pieśni o Lisowczykach, „Pamiętnik Literacki” 1952, nr 40, s. 1036-1039.

Z. Mocarski, [rec.] Dr. K. Badecki: „Literatura mieszczańska w Polsce XVII wieku. Monografija bibliograficzna", Lwów 1925, str. 543. Tenże: Nieodszukane pierwodruki literatury mieszczańskiej w Polsce XVII w.” Lwów (osobne odbicie z „Pamiętnika Literackiego” r. XXII i XXIII wytłoczone na Międzynarodowy Kongres bibliotekarzy i przyjaciót książki w Pradze) 1926, str. 43, „Zapiski Towarzystwa Naukowego w Toruniu” 1926, t. 7, nr 4, s. $120-129$.

R. Sztyber, Wstęp, [w:] Wojciech Dembolęcki o lisowczykach wierszem i proza (1620-1621), wyd. R. Szyber, Warszawa 2011, s. 6-208.

K.W. Wójcicki, Obrazy starodawne, t. 1, Warszawa 1843.

Zasady wydawania tekstów staropolskich. Projekt, przykłady, oprac. J. Woronczak, Wrocław 1955.

J.B. Zimorowic, Żywot kozaków lisowskich, ocenił i wyd. K.J. Heck, Lwów 1886, s. 33-67. 